\title{
The COVID-19 Vaccine and the Future of International Laws in Business, Travel, and Trade
}

\section{Melanie Lane}

J.D. Candidate, Pepperdine Caruso School of Law, Pepperdine University, 24255 Pacific Coast Hwy, Malibu, CA 90263, USA

E-mail for correspondence: melanie.lane@pepperdine.edu

\begin{abstract}
Since COVID-19, the world has been constantly evolving to adapt. Finding a cure quickly became the focus worldwide which altered set approaches to intellectual property rights. Additionally, creating a controversial vaccine has led to several more questions for the future. With varying vaccines and standards throughout the world, travel, business, and trade may face new challenges which change the current systems.
\end{abstract}

Keywords: COVID, Doha declaration, intellectual property, travel, international business, trade, international law

\section{INTRODUCTION}

The coronavirus vaccine is challenging several intellectual property as well as other seemingly foundational laws. For example, how much can patent holders charge for a cure? Can governments force pharmaceutical companies to create a generic drug? Can governments mandate vaccinations? The international solution to coronavirus, will have having lasting effects that will outlive the virus. The novel coronavirus (COVID-19 ${ }^{1}$ ), disrupted the world at the beginning of 2020, has since infected hundreds of millions of people, and left millions dead around the world. ${ }^{2}$ The United States alone has seen tens of millions of cases, with

\footnotetext{
1 About COVID-19, CNTR'S FOR DISEASE CONTROL AND PREVENTION (Sept. 1, 2020) https: / / www.cdc.gov / coronavirus / 2019ncov/cdcresponse/about-COVID-19.html ("In COVID-19, 'CO' stands for 'corona,' 'VI' for 'virus,' and 'D' for disease.").

${ }^{2}$ Covid World Map: Tracking the Global Outbreak, N.Y. TIMES (Jan. 10 , 2020)

https:/ / www.nytimes.com/interactive/2020/world/coronaviru s-maps.html; see Trisha Torrey, Difference Between an Epidemic and a Pandemic, VERYWELl HEALTH (May 5, 2020) https:/ / www.verywellhealth.com/difference-betweenepidemic-and-pandemic-2615168 ("An epidemic is an event in which a disease is actively spreading. In contrast, the term pandemic relates to geographic spread and is used to describe a disease that affects a whole country or the entire world.").

${ }^{3}$ Covid World Map: Tracking the Global Outbreak, supra note 2.
}

hundreds of thousands of deaths. ${ }^{3}$ Although the Center for Disease Control and Prevention (CDC) provided recommendations such as wearing a mask and staying at least six feet away from others, the coronavirus pandemic continued to spread throughout the world. ${ }^{4}$ The United States faced three major waves in one year alone, causing mass spreading, where daily new cases got as high as $45,000 .^{5}$ Although the virus affected at least 180 countries, the United States makes up one-third of all reported cases. ${ }^{6}$

Coronavirus is an airborne, respiratory virus that can cause coughing, chills, aches, nausea, loss of taste and smell, fever, and more. ${ }^{7}$ Once the virus has entered the body, it

\footnotetext{
${ }^{4}$ How to Protect Yourself \& Others, CNTR.'S FOR DISEASE CONTROL AND PREVENTION (Dec 31, 2020) https:/ / www.cdc.gov/coronavirus /2019-ncov/prevent-gettingsick/prevention.html.

${ }^{5}$ Chris Wilson \& Jeffrey Kluger, Alarming Data Show a Third Wave of COVID-19 Is About to Hit the U.S., TIME (Sept. 28, 2020) https:/ / time.com/5893916/covid-19-coronavirus-third-wave/.

6 Vasanthi Vara, Coronavirus outbreak: The countries affected, Pharmaceutical TeCH. (last updated Apr.16, 2020) https://www.pharmaceuticaltechnology.com/features/coronavirus-outbreak-the-countriesaffected/.

${ }^{7}$ Lauren M. Sauer, What is Coronavirus?, JOHNS HoPKINS MED., https://www.hopkinsmedicine.org/health/conditions-anddiseases/coronavirus (last updated Jan. 11, 2020).
} 
may take as many as fourteen days to experience symptoms. ${ }^{8}$ There are several strains of coronavirus, but the particular strain infecting the world was discovered in China in December of 2019. ${ }^{9}$

Although people continued to try to decrease the spread of the virus, it appeared that the best, and potentially only, solution would be a vaccine. ${ }^{10}$ Although countries such as Sweden tried to avoid lockdowns by attempting herd immunity, ${ }^{11}$ the World Health Organization (WHO) only supports herd immunity through vaccination. ${ }^{12}$ "'Herd immunity', also known as 'population immunity,' is the indirect protection from an infectious disease that happens when a population is immune either through vaccination or immunity developed through previous infection."13

However, several questions remain such as: How much will the vaccine cost? Will it be safe? How will the future of travel look? And most importantly, how will it affect current laws?

A patent holder has exclusive rights and will be able to control the price and distribution of his or her product, including vaccine patents. ${ }^{14}$ Because of the rights afforded to patent holders, the potential danger of high prices and patent abuse arise with the possible monopoly of the patent. ${ }^{15}$ If a there are no meaningful competitors and a patent holder decides to set the price high, some people may not be able to afford the drug necessary for a cure. Although vaccines generally take several years to reach the market, the race to end coronavirus sped up the process making vaccines available to the public within a year. ${ }^{16}$

\footnotetext{
${ }^{8} I d$.

${ }^{9} \mathrm{Id}$.

${ }^{10}$ See Benefits of Getting a COVID-19 Vaccine, CNTR'S FOR DISEASE CONTROL,), https://www.cdc.gov/coronavirus/2019ncov/vaccines/vaccine-benefits.html (last updated Jan. 5, 2021).

${ }^{11}$ Reuters Staff, Fact check: Serden has not achieved herd immunity, is not proof that lockdowns are useless, REUTERS (Dec. 2, 2020) https:/ / www.reuters.com/article/uk-factcheck-pragerusweden-herd-immunit/fact-check-sweden-has-not-achievedherd-immunity-is-not-proof-that-lockdowns-are-uselessidUSKBN28C2R7 (noting that Sweden's fatality rate is higher than several other countries, including the United States).

${ }^{12}$ Coronavirus disease (COVID-19): Herd immunity, lockdowns and COVID-19, WORLD HEALTH ORG. (Dec. 31, 2020) https:/ / www.who.int/news-room/q-a-detail/herd-immunitylockdowns-and-covid-19; see COVID-19 Vaccine Key to Reaching 'Herd Immunity,' Mo. UNIV. HEALTH CARE (last visited Feb. 13, 2021), https://www.muhealth.org/our-stories/covid-19vaccine-key-reaching-herd-immunity (using the Measles in the U.S. to explain that herd immunity requires $80-90 \%$ of the population).

${ }^{13} \mathrm{Id}$.

${ }^{14}$ Nicole DeAbrantes, Vaccines ... Patent Eligible Now or No? An Assessment of the Patent Eligibility of an Ebola Vaccine in Light of Recent Supreme Court Decisions, 44 AIPLA Q.J. 521, 533 (2016).
}

Distribution to other countries, specifically lesser developed countries, is another question to be answered in due time by the different patent holders. All World Trade Organization (WTO) members must adhere to the rules set forth in the Trade-Related Intellectual Property Rights agreement (TRIPS) which mandates member countries to provide minimum protections for patent holders. ${ }^{17}$ However, the agreement provides some flexibility that limits the patent holder's exclusivity in certain cases, such as national security or emergency, which may be deemed applicable in the case of a global pandemic. ${ }^{18}$

The future of travel is still unknown to many. Planes, theme parks, and other crowded locations have created several new rules such as masks, social distancing, temperature checks, and even, potentially, virtual lines. ${ }^{19}$ Further complications may arise if other countries mandate vaccination, which some say is "very possible." ${ }^{20}$ However, based on precedent set in Jacobson $v$. Commonwealth of Massachusetts, the United States may allow individual states to mandate compulsory vaccinations as well. ${ }^{21}$ The future of business remains unclear in the time of COVID-19.

Coronavirus has sent shockwaves through the global legal system. The virus has led to pressure on current intellectual law as well as individual liberties that affect the daily lives of people in all countries. Global responses are leading to new laws and regulations unprecedented in any way. ${ }^{22}$ International travel and trade will forever be changed by the regulations that come with the new coronavirus.
${ }^{15} I d$.

${ }^{16}$ Carl Zimmer, Jonathan Corum, \& Sui-Lee Wee, Coronavirus Vaccine Tracker, N.Y. TIMES (last updated Jan. 9, 2020) https://www.nytimes.com/interactive/2020/science/coronavir us-vaccine-tracker.html.

${ }^{17}$ WHO \& WTO, WTO Agreements \& Public Health, 29, 38, 45 https://www.wto.org/english/res_e/booksp_e/who_wto_e.pd $\mathrm{f}(2002)$.

${ }^{18} \mathrm{Id}$.

${ }^{19}$ Hannah Sampson and Natalie B. Compton, 11 Ways the Pandemic Will Change Travel, THE WASH. POST (June 15, 2020) https:/ /www.washingtonpost.com/travel/2020/06/15/11ways-pandemic-will-change-travel/.

${ }^{20}$ Monica Buchanan Pitrelli, No vaccine, no service: How vaccinations may affect travel plans in the future, CNBC (Jan. 14, 2020, 3:42 AM EST), https://www.cnbc.com/2021/01/14/will-vaccines-berequired-to-fly-or-travel-its-likely-say-

experts.html\#: :text=Traveling\%20abroad,Reserve\%20Universit y\%20School\%20of\%20Law.

${ }^{21}$ See Jacobson v. Commonwealth of Massachusetts, 197 U.S. 11 (1905).

${ }^{22}$ State Action on Coronavirus (COVID-19), NAT'L CONFERENCE OF STATE LEGISLATURES (Feb. 19, 2021), https: / www.ncsl.org/research/health/state-action-oncoronavirus-covid-19.aspx. 
Section II will discuss the background of vaccine production and the United States' health and approval standards for vaccines. Section III explains patenting vaccines in the United States as well as globally according to the TRIPS agreement. Additionally, Section III will cover the potential remedies and suggestions from countries around the world regarding patent and intellectual property sharing during a pandemic. Section IV sets forth the potential future implications and what the best future options are. Finally, Section $\mathrm{V}$ will conclude the paper with a brief summary and what the future of COVID-19 looks like.

\section{BACKGROUND OF V ACCINES}

The life of a vaccine is normally a long and complex process that takes several years to perfect. ${ }^{23}$ With the global demand for a cure, countries have fast tracked the process for the Coronavirus vaccine. ${ }^{24}$

\section{A. The Typical Life of Vaccine Production}

A typical vaccine takes between ten and fifteen years to develop. ${ }^{25}$ With the combination of private and public development, there are several different phases for the vaccine to pass before becoming available to the public. ${ }^{26}$

The exploratory stage is the first step in vaccine development. ${ }^{27}$ This stage generally takes between two and four years, and it involves laboratory research to determine potential antigens that can prevent diseases. ${ }^{28}$ In 2020, biotech company, Moderna, completed Phase I in under three months, an unprecedentedly short amount of time. ${ }^{29}$ The next stage is the preclinical stage which lasts

23 Vaccine Development, Testing, and Regulation, HISTORY OF VACCINES,

https://www.historyofvaccines.org/content/articles/vaccinedevelopment-testing-and-regulation (last visited Dec. 20, 2020).

${ }^{24}$ Carolyn Kormann, The Coronavirus Vaccine is on Track to be the Fastest Ever Developed, THE NEW YORKER (May 22, 2020) https:/ / www.newyorker.com/science/medical-dispatch/thecoronavirus-vaccine-is-on-track-to-be-the-fastest-everdeveloped.

${ }^{25}$ Vaccine Development, Testing, and Regulation, supra note 23.

${ }^{26} I d$.

${ }^{27} I d$.

${ }^{28} I d$.

${ }^{29}$ Kormann, supra note 24 .

${ }^{30}$ Vaccine Development, Testing, and Regulation, supra note 23.

${ }^{31} \mathrm{Id}$.

${ }^{32}$ Id.; FDA Responsibilities of Sponsors and Investigators, 21 C.F.R. § 312.50 (2020) ("Sponsors are responsible for selecting qualified investigators, providing them with the information they need to conduct an investigation properly, ensuring proper monitoring of the investigation(s), ensuring that the investigation(s) is conducted in accordance with the general investigational plan and protocols contained in the IND, maintaining an effective IND with respect to the investigations, one to two years. ${ }^{30}$ This stage involves animal testing to determine the safety of the vaccine. ${ }^{31}$

Next, a private sponsor will complete an FDA application for the vaccination as an Investigational New Drug (IND), and then "[t]he FDA has [thirty] days to approve the application." ${ }^{32}$ Once the FDA approves the vaccine, it will move to the trial phases of the developmental process. ${ }^{33}$

Phase I of the vaccine trial allows scientists to administer the drug on a group of twenty to eighty adults to determine the safety and potential immune responses in humans. ${ }^{34}$ Phase I normally takes months to complete while "[r] esearchers look for expected reactions to the vaccine." ${ }^{\prime 35}$

Phase II will not begin until there is "promising" progress in the Phase I trial. ${ }^{36}$ The Phase II trial will generally be administered to several hundred people and may include placebo doses. ${ }^{37}$ During the pandemic research, this phase included adults ages eighteen to fifty-five as well as some over the age of sixty-five. ${ }^{38}$ This phase helps researches focus on finding the correct dosage. ${ }^{39}$

Phase III administers the vaccine to thousands of people and continues to test the vaccine safety for large numbers. ${ }^{40}$ During the entire process, researchers monitor the vaccine for safety before it can move to the final phase of development which is distributing the vaccine to the public. ${ }^{41}$ Phase IV, which is optional, allows for continued monitoring of safety and efficacy after the vaccine has been released to the public. ${ }^{42}$

Previously, the mumps vaccine was the fastest produced vaccine, taking four years to develop in the 1960s. ${ }^{43}$ Within 2020 alone, two vaccines made it through all the stages of

and ensuring that FDA and all participating investigators are promptly informed of significant new adverse effects or risks with respect to the drug.").

${ }^{33}$ Vaccine Development, Testing, and Regulation, supra note 23.

${ }^{34} \mathrm{Id}$.

${ }^{35}$ Hallie Levine, The 5 Stages of COVID-19 Vaccine Development: What You Need to Know About How a Clinical Trial Works, JOHNSON \& JOHNSON (Sept. 23, 2020), https:/ / www.jnj.com/innovation/the-5-stages-of-covid-19vaccine-development-what-you-need-to-know-about-how-aclinical-trial-works.

${ }^{36}$ Vaccine Development, Testing, and Regulation, supra note 23.

${ }^{37} \mathrm{Id}$.

${ }^{38}$ Levine, supra note 35.

${ }^{39} \mathrm{Id}$.

${ }^{40}$ Vaccine Development, Testing, and Regulation, supra note 23.

${ }^{41} \mathrm{Id}$.

${ }^{42} I d$.

${ }^{43}$ Amy Mckeever, Here's the latest on COVID-19 vaccines, NAT. GEO. (Dec 22, 2020),

https:/ / www.nationalgeographic.com/science/health-andhuman-body/human-diseases / coronavirus-vaccine-trackerhow-they-work-latest-developments-cvd/. 
clinical trials and cleared FDA approval to combat Coronavirus. ${ }^{44}$ America is not alone in their expedited vaccine trials as hundreds of other countries quickly develop vaccines, such as Russia, China, and the United Kingdom. ${ }^{45}$

\section{B. United States Vaccine Standards and Rules}

Beginning in the late nineteenth century and early twentieth century, the United States adopted several regulations ${ }^{46}$ to control the quality of drugs. ${ }^{47}$ Furthermore, "[t]he United States Public Service Act of 1944 mandated that the federal government issue licenses for biological products, including vaccines." 48 However, licensing became even stricter after an expedited vaccine release caused harm to the public. ${ }^{49}$ This release is now known as the Cutter Incident. ${ }^{50}$ In 1955, the United States released a polio vaccine to 200,000 children which ended up causing 40,000 cases of polio and killing ten children. ${ }^{51}$ After the incident, the government created the Division of Biologics Standards, which later became part of the FDA. ${ }^{52}$ Additionally, the incident "led to the effective federal regulation of vaccines, which today enjoy a record of safety 'unmatched by any other medical product.'"53

Although the incident led to more protective measures before authorization, the FDA is still able to grant Emergency Authorization Use (EAU) in the event of a domestic health emergency. ${ }^{54}$ Although they provide several recommended guidelines for an EAU application, they do not require the manufacturers to take all the recommended steps before authorizing a vaccine. ${ }^{55}$ EAU

\section{${ }^{44} I d$.}

45 See id.; Zimmer et al., supra note 16.

${ }^{46}$ Lisa N. Sacco, Drug Enforcement in the United States: History, Policy, and Trends, CONGRESSIONAL RESEARCH SERVICE 2-3(2014) https://fas.org/sgp/crs/misc/R43749.pdf (stating that the Harrison Act helped regulate drugs through taxation and record keeping, and the Federal Bureau of Narcotics was established for enforcement purposes).

47 Vaccine Development, Testing, and Regulation, supra note 23.

${ }^{48} \mathrm{Id}$.

${ }^{49}$ Michael Fitzpatrick, The Cutter Incident: How America's First Polio Vaccine Led to a Growing Vaccine Crisis, J. OF THE ROYAL SOC'Y OF MED. (Mar. 2006), https://www.ncbi.nlm.nih.gov/pmc/articles/PMC1383764/. ${ }^{50} \mathrm{Id}$.

${ }^{51} I d$.

${ }^{52}$ Vaccine Development, Testing, and Regulation, supra note 23.

${ }^{53}$ Fitzpatrick, supra note 49.

${ }^{54}$ US Department for Health \& Human Services, Food and Drug Administration, et al., Emergency Use Authorization of Medical Products and Related Authorities, 22 (Jan. 2017), https://www.fda.gov/media/97321/download [hereinafter FDA Emergency Authorization].

${ }^{55}$ Id.; Fran Kritz, What's the Difference Between Emergency Use Authorization and Approval?, VerYWell HEALTH, (Dec. 18, 2020) https:/ / www.verywellhealth.com/emergency-use- also significantly reduces the information that manufacturers must provide to authorized distributors and recipients as well as the labeling restrictions for the drug. ${ }^{56}$ For both authorized distributors and recipients, the FDA requires users to be informed "[t]hat [the] FDA has authorized emergency use of the product," the known risks and benefits, and the available alternatives. ${ }^{57}$ Additionally, researchers must inform recipients "[t]hat they have the option to accept or refuse the EAU product as well as of any consequences of refusing administration of the product."

At the time of this paper, the FDA issued two EUAs for two different coronavirus vaccines, with the expectation they would continue to monitor the vaccines' safety. ${ }^{59}$

\section{Current United States and International INTELLECTUAL PROPERTY LAW}

Current domestic and international laws provide some insight into potential problems and solutions to the current pandemic. To begin, intellectual property-including vaccine patents-are well protected in the United States as well as in many foreign countries. ${ }^{60}$ Although intellectual property protections are both important and necessary, implications may, in effect, delay a potential decrease in virus spreading by inhibiting vaccine distribution. ${ }^{61}$

\section{A. Vaccines as Patents}

Patents have been around for hundreds of years and even maintain a spot in the United States Constitution along

authorization-vs-approval-5092864 (noting that less data is required from trials). But see Joshua Sharfstein, What is Emergency Use Authorization?, JOHNS HOPKINS BlOOMBERG SCH. OF PUB. HEALTH (Oct. 20, 2020), https://www.jhsph.edu/covid19/articles/what-is-emergency-use-authorization.html (noting that Emergency Use Authorization still requires a minimum protection requiring the benefits outweigh risks).

${ }^{56}$ FDA Emergency Authorization, supra note 54, at 22-24.

${ }^{57}$ Id.; See Zachary Brennan, Why FDA's Issuance of EUAs are not 'approvals' and why that matters, REGULATORY AFFAIRS PROF'L SOC'Y (Apr. 3, 2020) https://www.raps.org/news-andarticles/news-articles/2020/4/why-fdas-issuance-of-euas-arenot-approvals-and-wh (nothing that health care providers were told the product "may be effective," which would not happen if the FDA gave their full approval of the product).

${ }^{58}$ FDA Emergency Authorization, supra note 54, at 24.

${ }^{59}$ FDA Takes Additional Action in Fight Against COVID-19 By Issuing Emergency Use Authorization for Second CVOID-19 Vaccine, U.S. FOOD \& DRUG ADMIN. (Dec. 18, 2020) https:/ / www.fda.gov/news-events/press-announcements/fdatakes-additional-action-fight-against-covid-19-issuingemergency-use-authorization-second-covid.

${ }^{60}$ WTO Agreements \& Public Health, supra note 17, at 11.

${ }^{61}$ See Nasos Koukakis, Countries worldwide look to acquire the intellectual property rights of Covid-19 vaccine makers, CNBC, https://www.cnbc.com/2021/01/22/countries-look-to-acquirethe-ip-of-vaccine-makers-to-fight-pandemic.html (last updated Jan. 22 2021, 11:15 AM EST). 
with federal laws dating back to $1790 .{ }^{62}$ "Whoever invents or discovers any new and useful process, machine, manufacture, or composition of matter, or any new and useful improvement thereof, may obtain a patent therefor[e], subject to the conditions and requirements of this title." ${ }^{\prime 63}$

Patent holders have the ability to make, use, sell, license, and exclude others from using the patent, which gives them ample freedom to protect their intellectual property. ${ }^{64}$

Patents are generally available for vaccines so long as they are not natural substances. ${ }^{65}$ Nicole DeAbrantes, writing in the American Intellectual Property Law Association Quarterly Journal, explains the advantages of patenting vaccines by saying, "[t]he United States patent system has allowed many scientists to develop vaccines and obtain exclusive rights to their inventions. Patents provide incentives to inventors whose discoveries will help to 'advance the public good.'”66

In her article, DeAbrantes discusses the need and potential for an Ebola vaccine at the time of heightened concern if the virus. ${ }^{67}$ The author points to the Interim Guidelines provided in the Supreme Court case, Alice Corp. v. CLS Bank International, that state, "nature-based products are patent eligible if the product contains a markedly different characteristic from 'its naturally occurring counterpart.' Markedly different characteristics include structure, functions, chemical properties, and other properties." 68 Therefore, the makeup of the vaccine or drug will determine whether it is eligible for patent protection.

Although patents provide an incentive for research and development by granting wide control, there are potential

${ }^{62}$ A Brief History of the Patent Law of the United States, LADAS \& PARRY (May 7, 2014) https://ladas.com/education-center/abrief-history-of-the-patent-law-of-the-united-states-2/.

${ }^{63} 35$ USCA § 101.

64 Patent Basics, INVENTIV FOUNDATION, https://www.inventiv.org/patentfaqs/patent-basics/ (last visited Dec. 28, 2020) ("Depending on the type of patent, the exclusive right lasts for 15-20 years."

${ }^{65}$ DeAbrantes, supra note 14 , at 526.

${ }^{66} \mathrm{Id}$.

${ }^{67}$ Id. at $523,525$.

${ }^{68} \mathrm{Id}$. at $525-26$.

${ }^{69}$ S. Vincent Rajkumar, The High Cost of Insulin in the United States: An Urgent Call to Action, MAYO CLINIC PROCEEDINGS (Jan. 1, 2020) https:/ / www.mayoclinicproceedings.org/article/S00256196(19)31008-0/fulltext.

${ }^{70} \mathrm{Id}$.

${ }^{71} I d$.

${ }^{72}$ Why People with Diabetes Can't Buy Generic Insulin, JOHNS HOPKINS MED. (Mar. 18, 2015) https://www.hopkinsmedicine.org/news/media/releases/wh y_people_with_diabetes_cant_buy_generic_insulin. countervailing issues that arise with such freedoms, such as monopolies over patents. ${ }^{69}$ One example of patent abuse is insulin prices in the United States, which can cost "10 times more in the United States than in any other developed country" even though the drug is a necessity for millions of people to survive. ${ }^{70}$ Additionally, although insulin has been around for a long time, the updated developments cause patent evergreening, which allows the patent holder to essentially extend the patent forever. ${ }^{71}$ The insulin patent has been in effect since 1923 due to evergreening. ${ }^{72}$ Patent evergreening is the slight modification of a previous drug, which extends the patent life and sometimes adds no real benefit for the general population. ${ }^{73}$ Depending on who the patent holder is, there may be a potential for heightened prices or patent evergreening.

Companies have also taken advantage of the potential market as stock prices skyrocket when a company announces its intention to develop a COVID-19 vaccine. ${ }^{74}$ Although private companies are generally responsible for vaccine development, ${ }^{75}$ the United States Department of Health and Human Services has agreed to fund some of the vaccine development with certain companies. ${ }^{76}$ Additionally, in May of 2020, then president, Donald Trump stated that he hoped to make the vaccine free to the public, ${ }^{77}$ and President Joe Biden stated in January of 2021 that he planned to distribute 100 million vaccines in his first 100 days in office. $^{78}$

There have been examples of free vaccine use in the past, such as the second Polio vaccine created by Jonas Salk. ${ }^{79}$ Because up to twenty thousand people contracted some sort of paralysis from Polio each year, Salk decided not to

${ }^{73}$ Roger Collier, Drug patents: the evergreening problem, CAN. MED. Ass' $^{N} \quad$ J. (Jun 11, 2013) https://www.ncbi.nlm.nih.gov/pmc/articles/PMC3680578/.

${ }^{74}$ David Gelles \& Jesse Drucker, Corporate Insiders Pocket \$1 Billion in Rush for Coronavirus Vaccine, N.Y. TIMES (July, 25, 2020) https: / /www.nytimes.com/2020/07/25/business/coronavirusvaccine-profits-vaxart.html.

${ }^{75}$ Sarah Kliff, The U.S. Commits to Buying Millions of Vaccine Doses. Why That's Unusual., N.Y. TIMES (July 22, 2020) https://www.nytimes.com/2020/07/22/upshot/vaccinecoronavirus-government-purchase.html

${ }^{76}$ Gelles, supra note 74 .

${ }^{77}$ Morgan Chalfant, Trump says administration is 'looking at' making coronavirus vaccine free, 2020 THE HILL 498080 (May 15, 2020).

${ }^{78}$ Sheryl Gay Stolberg and Sharon LaFraniere, Biden Promises 100 Million Vaccine Shots in 100 Days, but Shortage Worries Rise, N.Y. TIMES (Jan. 8, 2021) https:/ / www.nytimes.com/2020/12/08/us/politics/bidencoronavirus-vaccine.html.

${ }^{79}$ Deborah Levine, The case for a free or inexpensive Coronavirus Vaccine, WASH. POST (Mar. 2, 2020), https:/ / www.washingtonpost.com/outlook/2020/03/02/casefree-or-inexpensive-coronavirus-vaccine/ 
patent his vaccine and make it freely available to the public. ${ }^{80}$ In essence, he forfeited his right for the greater societal good. ${ }^{81}$ Therefore, much of the outcome for the vaccine could rest on the inventor.

Near the end of 2020, the Health Resources and Services Administration confirmed that the vaccine will be free for Americans during the pandemic if they have, either, private health insurance or are uninsured, which potentially leaves out those with alternative healthcare plans like short term insurance. ${ }^{82}$ Holders of alternative healthcare plans, therefore, may have a copay obligation. ${ }^{83}$ There is no promise that the vaccine will continue to be free once the pandemic is over, but some speculate it could be more expensive than a flu vaccine due to the cooling requirement of some of the vaccines. ${ }^{84}$

\section{B. International Trading and TRIPS}

Beyond domestic laws, the United States, along with several other countries, must comply with the WTO standards. ${ }^{85}$ The WTO was established in 1995 and 164 countries currently belong as members. ${ }^{86}$ The goal of the WTO "is to help producers of goods and services, exporters, and importers conduct their business." ${ }^{87}$ The WTO offers dispute processes for countries when they do not act within the agreements set forth. ${ }^{88}$ Within the WTO are several more agreements, including the Trade-Related Intellectual Property Rights agreement, or TRIPS. ${ }^{89}$ "The TRIPS Agreement requires WTO Members to establish minimum standards for protecting and enforcing

\footnotetext{
${ }^{80} \mathrm{Id}$.

${ }^{81} \mathrm{Id}$.

${ }^{82}$ Julia Ries, You Won't Have to Pay for a COVID-19 Vaccine, At Least in the Beginning, HEALTHLINE (Dec 10, 2020), https:/ / www.healthline.com/health-news / you-wont-have-topay-for-a-covid-19-vaccine-during-the-pandemic

${ }^{83} \mathrm{Id}$.

${ }^{84} \mathrm{Id}$.

85 See Overview: a navigational guide, WORLD TRADE ORG. https://www.wto.org/english/thewto_e/whatis_e/tif_e/agrm 1_e.htm.

86 WTO, What is the WTO?, WORLD TRADE ORG. https://www.wto.org/english/thewto_e/whatis_e/whatis_e.ht $\mathrm{m}$

${ }^{87} \mathrm{Id}$.

${ }^{88}$ Corrs Chambers Westgarth, The role of the WTO in international trade post COVID-19, LEXOLOGY (June 4, 2020) https:/ /www.lexology.com/library/detail.aspx?g=1d0ab073de42-4be9-961d-593c7d5adca5 (criticizing the long process of finding an agreement during the global pandemic).

${ }^{89}$ WTO Agreements \& Public Health, supra note 17, at 11.

${ }^{90} \mathrm{Id}$. at 38

${ }^{91} I d$. at 39.

${ }^{92}$ Id. at 43; Is My U.S. Patent Good in Other Countries?, STOPFAKES (last published Oct. 17, 2018)
} https: / / www.stopfakes.gov/article?id=Is-My-US-Patent-Good- intellectual property rights." ${ }^{90}$ Such required property rights include protections for patents. ${ }^{91}$

Although TRIPS requires a patent to be new, nonobvious, and useful, the exact requirements vary by each memberstate's laws. ${ }^{92}$ Although a majority of restrictions are left to each member-state to decide (including patent standards) TRIPS requires all WTO members to allow at least twenty years for a patent to last, with a few exceptions. ${ }^{93}$ Although a patent may be granted to "prevent others from making, using, or selling the new invention," it does not permit unauthorized market use. ${ }^{94}$

Although the WTO prohibits unauthorized market use, Article 31 of the TRIPS agreement allows for use in specific instances. ${ }^{95}$ A compulsory license may be granted if there is a "national emergency" or another "example of extreme urgency," but does not specify or limit the definition of such emergencies. ${ }^{96}$ Under a compulsory license, each government may determine what qualifies as a national emergency in its state as long as it meets the conditions set forth in the TRIPS agreement. ${ }^{97}$ However, in order to implement compulsory licenses, countries must enact local legislation. ${ }^{98}$ Many countries previously failed to enact local legislation making Article 31 "non-operational." 99 Article 31 limited such grants when first enacted. ${ }^{100}$ The Article reads "any such use shall be authorized predominantly for the supply of the domestic market of the Member authorizing such use," which prohibits countries without manufacturing resources from using Article 31. ${ }^{101}$

in-Other-Countries (describing several rules popular in foreign countries, such as requiring maintenance fees, manufacturing requirements, and restrictions that the United States does not use in its domestic laws).

${ }^{93}$ WTO Agreements \& Public Health, supra note 17, at 42.

${ }^{94} \mathrm{Id}$. at 44 .

95 Id. at 45; Obligations and exceptions, WORLD TRADE ORG., https://www.wto.org/english/tratop_e/trips_e/factsheet_phar m02_e.htm (last visited Feb. 11, 2020) ("Compulsory licensing is when a government allows someone else to produce the patented product or process without the consent of the patent owner.").

96 WTO Agreements \& Public Health, supra note 17, at 45

${ }^{97} \mathrm{Id}$.

${ }^{98}$ William Alan Reinsch, Jack Caporal, \& Sanvid Tuljapurker, Compulsory Licensing: A Cure for Distributing the Cure?, CNTR. FOR STRATEGIC \& INT. STUDIES (May 8, 2020), https://www.csis.org/analysis/compulsory-licensing-curedistributing-cure; Hilary Wong, The case for compulsory licensing during COVID-19, J GLOB HEALTH (June 2020) https://www.ncbi.nlm.nih.gov/pmc/articles/PMC7242884/.

${ }^{99} \mathrm{Id}$.

100 TRIPS: Agreement on Trade-Related Aspects of Intellectual Property Rights, Apr. 15, 1994, Marrakesh Agreement Establishing the World Trade Organization, art. 31(f) 1869 U.N.T.S. 299 (1994) [hereinafter TRIPS Agreement].

${ }^{101} I d$. 
In order to fix this problem, the WTO, under the Doha Declaration in 2003, which only took effect recently, in $2017^{102}$, amended Article 31 to include Article 31bis to accommodate countries with inadequate pharmaceutical manufacturing. ${ }^{103}$ Before $31 \mathrm{bis}$, countries were only able to grant compulsory licensing if they were able to manufacture and distribute the drug in their own country, leaving many lesser developed countries without access to necessary medicines. ${ }^{104}$ Article 31 bis now allows countries to import those patented drugs so long as the countries meet the specified guidelines and register with the WTO. ${ }^{105}$ Additionally, the patent holder must still receive remunerations for the use of the patent under all kinds of compulsory licenses, which will be decided by "taking into account the economic value of authorization."106

For example, in the early 2000s, India was in need of a cheap and available vaccine when the potential for bird fly infections was on the rise. ${ }^{107}$ An Indian pharmaceutical company wanted to create a generic, cheaper version of Tamiflu to distribute in case of a pandemic. ${ }^{108}$ Although the patent holders had reluctantly donated three million doses to the WHO, the amount would be ineffective in the event of a widespread pandemic, and the generic prices were too high for the Indian population. ${ }^{109}$ The ultimate question in the situation was determining whether bird flu could be characterized as a "national emergency" and how that would affect India's membership in the WTO. ${ }^{110}$ However, before the disagreement progressed, India's threat of

102 Diane Desierto, Equitable COVID Vaccine Distribution and Access: Enforcing International Legal Obligations under Economic, Social, and Cultural Rights and the Right to Development, EJIL:TALK! (Feb. 2, 2021), https:/ / www.ejiltalk.org/equitable-covid-vaccinedistribution-and-access-enforcing-international-legal-

obligations-under-economic-social-and-cultural-rights-and-theright-to-development/.

${ }^{103}$ Carlos M. Correa, Will the Amendment to the TRIPS Agreement Enhance Access to Medicines?, SOUTH CENTRE, No. 57, 1, Jan 2019.

${ }^{104} I d$.

${ }^{105} \mathrm{Id}$. at 2 .

${ }^{106}$ WTO Agreements \& Public Health, supra note 54, at 45.

${ }^{107}$ Aditi Diya Nag, The Bird Flu and the Invoking of Trips Article 31 "National Emergency" Exception, 34 SYRACUSE J. INT'L L. \& COM. 689 (2007).

${ }^{108} I d$. at 699.

${ }^{109}$ Id. at $689,703-04$

${ }^{110} \mathrm{Id}$. at 700-01.

111 Jerome H. Reichman, Compulsory licensing of patented pharmaceutical inventions: evaluating the options, J. LAW MED ETHICS (Jul. 1 , 2010),

https://www.ncbi.nlm.nih.gov/pmc/articles/PMC2893582/.

112 Christopher Garrison, Never say never - Why the High Income Countries that opted-out from the Art. 31bis WTO TRIPS system must urgently reconsider their decision in the face of the Covid-19 pandemic, MED. LAW \& POLICY (Apr. 8, 2020) https:/ / medicineslawandpolicy.org/2020/04/never-say-neverwhy-the-high-income-countries-that-opted-out-from-the-art- compulsory license use led to an agreement with the pharmaceutical company to help provide the vaccines to India. ${ }^{111}$ The situation shows the potential disputes arising between patent holders and countries who deem themselves to be in a national emergency, such as the current global pandemic. So, the question remains: why have countries not been using Article 31?

To begin, many countries, specifically high-income countries, outsource active pharmaceutical ingredients (APIs) for cost benefits, mostly to India and China. ${ }^{112}$ While a country, such as the United States, may be able to grant a compulsory license, it cannot demand that the manufacturing country allow the export. ${ }^{113}$ Additionally, if a compulsory license is granted, "the Article 31(f) problem immediately presents itself," because the United States does not use domestic pharmaceutical operations. ${ }^{114}$

Therefore, in order to enact Article 31, outsourcing countries would need to make use of Article 31bis because the pharmaceuticals would not be made in the enacting country. ${ }^{115}$ However, some high income countries "unilaterally committed that they would not make use of the system as importers." ${ }^{116}$ Unfortunately, these countries did not create a fail-safe in case they needed to opt back into the system in the event of an emergency. ${ }^{117}$

Also, as mentioned earlier, countries must have a local legislative step in place to authorize such a compulsory

31bis-wto-trips-system-must-urgently-reconsider-their-decisionin-the-face-of-the-covid-19-pandemic/; see Sydney Lupkin, How Will Moderna Meet the Demand For Its COVID-19 Vaccine?, NPR (Dec. 17, 2020, 3:23 PM https:/ / www.npr.org/sections/health-

shots /2020/12/17/947628608/how-will-moderna-meet-thedemand-for-its-covid-19-vaccine (stating Pfizer has several manufacturing facilities located around the world).

${ }^{113} I d$.

${ }^{114}$ Id.; see Louis Garguilo, Outsourced Pharmaceutical Manufacturing Grows to $\$ 76$ Billion, OUTSOURCED PHARMA, https:/ / www.outsourcedpharma.com/doc/outsourcedpharmaceutical-manufacturing-grows-to-billion-0001 (last visited Feb. 13, 2020) (predicting outsourced manufacturing should increase faster than expected).

${ }^{115}$ Garrison, supra note 112.

${ }^{116}$ Id.; James Love, Open letter asking 37 WTO Members to declare themselves eligible to import medicines manufactured under compulsory license in another country, under 31bis of TRIPS Agreement, KNOWLEDGE ECOLOGY INT'L (Apr. 7, 2020), https://www.keionline.org/32707 (listing Australia, Austria, Belgium, Bulgaria, Canada, Croatia, Cyprus, Czechia, Denmark, Estonia, Finland, France, Germany, Greece, Iceland, Ireland, Italy, Japan, Latvia, Lithuania, Luxembourg, Malta, Netherlands, New Zealand, Norway, Poland, Portugal, Romania, Slovakia, Slovenia, Spain, Sweden, Switzerland, the United Kingdom, and the United States as countries that opted out of Article 31bis as importing countries).

${ }^{117}$ Garrison, supra note 112. 
license, which many countries have failed to do. ${ }^{118}$ Since the pandemic began, some countries such as Canada, Chile, and Ecuador updated their laws in order to lay the groundwork for a future vaccine or curative drug. ${ }^{119}$ However, several countries still lack the legal basis and need to update their laws in order to enact a compulsory license. ${ }^{120}$

However, some countries, such as Israel, have made use of compulsory licenses during the epidemic-creating a generic version of a drug thought to help with coronavirus when the manufacturer could not provide sufficient doses. ${ }^{121}$ The manufacturer of the drug responded by stating it would not enforce the patent. ${ }^{122}$ Israel's move shows the potential benefits and simplicity of compulsory licenses. ${ }^{123}$

In October of 2020, the WTO TRIPS council met to discuss potential approaches to the pandemic. ${ }^{124}$ India and South Africa proposed the idea of a waiver for certain TRIPS provisions during the COVID pandemic involving copyright, patents, and other related intellectual property rights. ${ }^{125}$ "The waiver would cover the 'implementation, application, and enforcement' of these sections as far as they apply to the 'prevention, containment, or treatment of COVID-19.'" 126 However, several countries opposed the proposed waiver, including the United States and the European Union, who argued that intellectual property rights were not a current hindrance in ending the pandemic. ${ }^{127}$ However, some speculate the opposition to the idea stems from the fact that the United States and the European Union already spent billions of dollars buying up promised doses of the vaccine. ${ }^{128}$ Regardless, the proposal will not pass unless the WTO members agree on an outcome, thus prohibiting the proposal from going further. ${ }^{129}$

\footnotetext{
${ }^{118}$ Wong, supra note 98.

${ }^{119} \mathrm{Id}$.

${ }^{120}$ Id.; see Matt D. Kohel, Two Ways Government Can Assume Patent Licensing Powers During COVID-19, GOODWILl DeVRIES BLOG (Apr. 22, 2020), https://www.gdldlaw.com/blog/two-ways-usgov-patent-licensing-powers (stating the United States can authorize a compulsory license under the 1980 Bayh-Dole Act or under 28 U.S.C. $§ 1498)$.

${ }^{121}$ Wong, supra note 98.

${ }^{122} \mathrm{Id}$.

${ }^{123}$ See id.

${ }^{124}$ Sofia Baliño, As Second Wave of COVID-19 Sweeps the Globe, WTO Members Mull Options for Pandemic Response, INT'L INST. FOR Sustainable DeV. (Oct. 28, 2020), https://sdg.iisd.org/commentary/policy-briefs/as-secondwave-of-covid-19-sweeps-the-globe-wto-members-mull-optionsfor-pandemic-response/

${ }^{125} \mathrm{Id}$.

${ }^{126} \mathrm{Id}$

${ }^{127} \mathrm{Id}$.
}

Further, countries have proposed potential avenues for shared communication regarding vaccine research and availability. ${ }^{130}$ For example, Costa Rica proposed a voluntary "pool of rights to tests, medicines, and vaccines, with free access or licensing on reasonable and affordable terms for all countries." ${ }^{131}$ Costa Rica's proposed plan is called COVID-19 Technology Access Pool (CTAP), which WHO adopted in May of $2020 .{ }^{132}$ CTAP is a voluntary pool that creates a free flow of information and research from its members to help facilitate an expedited and cost effective vaccine for coronavirus. ${ }^{133} \mathrm{~A}$ majority of the joining members of CTAP were low or middle-income States, although some high-income States also joined, such as Norway and the Netherlands. ${ }^{134}$

The push for CTAP came with a Solidarity Call to Action from WHO stating:

[W] call to action key stakeholders and the global community to voluntarily pool knowledge, intellectual property and data necessary for COVID19. Shared knowledge, intellectual property and data will leverage our collective efforts to advance scientific discovery, technology development and broad sharing of the benefits of scientific advancement and its applications based on the right to health. ${ }^{135}$

The call asks for more countries to join the effort in order to allow licenses to be free for all to use. ${ }^{136}$

Other supporters of CTAP, such as Muhammed Zaheer Abbas, a law lecturer in Pakistan, says that the Costa Rica idea is important because it impacts the two most pressing issues "(1) the urgent development of needed health technologies and (2) the equitable and affordable access to potential health technologies," which he believes the pool

\footnotetext{
${ }^{128}$ Charlotte Kilpatrick, Big Pharma could supply the whole world with a COVID vaccine. They've chosen not to, SALON (Nov 21, 2020) https://www.salon.com/2020/11/21/big-pharma-couldsupply-the-whole-world-with-a-covid-vaccine-theyve-chosennot-to/.

${ }^{129}$ Baliño, supra note 124

${ }^{130}$ Reinsch et al., supra note 98.

${ }^{131} I d$.

132 William Worley, WHO and Costa Rica launch COVID-19 Technology Access Pool, DEVEX, May 29, 2020 https://www.devex.com/news/who-and-costa-rica-launchcovid-19-technology-access-pool-97368.

${ }^{133} \mathrm{Id}$.

${ }^{134} I d$.

135 Solidarity Call to Action, WORLD HEALTH ORG., https://www.who.int/emergencies/diseases/novelcoronavirus-2019/global-research-on-novel-coronavirus-2019ncov/covid-19-technology-access-pool/solidarity-call-to-action (last visited, Jan. 20, 2021).

${ }^{136} I d$.
} 
will fix. ${ }^{137}$ Additionally, Abbas states that pooling is not a new idea, but that CTAP was most likely inspired by the Medicines Patent Pool (MPP) created in 2010. ${ }^{138}$ MPP came from growing concerns about other pandemics, such as SARS and H1N1. ${ }^{139}$ MPP signed agreements with organizations, such as Gilead Sciences, to share their patents. ${ }^{140}$ The MPP provides the intellectual property to companies who promise to manufacture the medicine for low or middle-income countries. ${ }^{141}$ CTAP differs from MPP because it would include all countries, not just middle and low-income countries, therefore, expanding the pool. ${ }^{142}$

However, global trends show the opposite is happening with regards to the COVID-19 vaccine. The United States has been outbidding other countries for the vaccine patent and other intellectual property while other countries have hoarded medicine, such as hydroxychloroquine, when rumors of its healing properties toward COVID-19 patients started to spread. ${ }^{143}$ Additionally, the CEO of Pfizer, one of the major players in the coronavirus vaccine, stated CTAP is "nonsense" and potentially dangerous at this point in vaccine development. ${ }^{144}$

The opposition to CTAP most likely stems from the financial gain coming from patents. Gilead, who is a member of the MPP, made Remdesivir, a medicine being used for COVID, at a global price of $\$ 390$ per day, when the cost to make is less than $\$ 1 .{ }^{145}$ The profit potential will, thus, be lost if the pharmaceutical companies allow for their drugs to become voluntary licenses. ${ }^{146}$

A few more countries proposed other efforts on a smaller scale, such as one by Spain's science minister to pool European Union efforts and funds. ${ }^{147}$ However, there are skeptics who state that although there are benefits to these ideas, such as stimulating research, there is little these efforts will do to help the current global health crisis. ${ }^{148}$

${ }^{137}$ Muhammed Zaheer Abbas, Treatment of the novel COVID-19: why Costa Rica's proposal for the creation of a global pooling mechanism deserves serious consideration?, J LAW BIOSCI (Jun 26, 2020), https://www.ncbi.nlm.nih.gov/pmc/articles/PMC7337827/\#fn 12.

${ }^{138} \mathrm{Id}$.

${ }^{139} \mathrm{Id}$.

${ }^{140}$ Id.; About Us, MED. PATENT POOL (last visited Feb. 13, 2020) https:/ / medicinespatentpool.org/ (stating MPP is backed by the United Nations to help create generic drugs by partnering with governments, patent groups, and more).

${ }^{141}$ Abbas, supra note 137.

${ }^{142} \mathrm{Id}$.

${ }^{143}$ Helen Toen, How the World Can Put Sharing Above Profits in the Race for a Vaccine, BARRON'S (Apr. 16, 2020), https:/ / www.barrons.com/articles/a-vaccine-for-all-not-ifthese-companies-and-countries-have-their-way-51586976476.

${ }^{144}$ Worley, supra note 132
The push back mostly comes from the countries that have bought several million doses of the vaccine, such as the United States. ${ }^{149}$ The countries propose that poorer countries should use compulsory licensing rather than pooling in order to get access to the vaccine and other potentially helpful drugs. ${ }^{150}$

Even if CTAP or other pooling ideas do not catch on with higher-income countries, governments may be able to use Article 31 of TRIPS, as stated previously. However, this may be of little or delayed help to countries without pharmaceutical manufacturing because other countries will most likely not export any vaccines until their own country is vaccinated first. Thus, vaccines will only get to those countries later.

Therefore, the solution for vaccine distribution presents several potential issues. In order to get CTAP off the ground and more widespread, the WHO needs to develop better incentives for countries and manufacturers to encourage their participation. Some potential incentives could be tax breaks or pooling of funds and capital. Although to be effective, any initiative would need mass participation.

\section{How is the Coronavirus Vaccine Being Treated Differently ${ }^{151}$}

Through "Operation Warp Speed," the United States has taken a rapid approach to developing the Coronavirus vaccine and has promised $\$ 10$ billion to further those efforts. ${ }^{152}$ It is highly unusual for the United States government to pay for vaccinations or vaccine development, but the Trump administration purchased 100 million doses for distribution before the vaccine was even ready. ${ }^{153}$ By February of 2021, the United States contracted for 500 million doses with companies such as Johnson \& Johnson and AstraZeneca. ${ }^{154}$ During the pandemic, pharmaceutical companies ran trial phases concurrently rather than consecutively as they normally

\footnotetext{
${ }^{145}$ Kilpatrick, supra note 128.

${ }^{146} \mathrm{Id}$.

${ }^{147}$ Reinsch et al., supra note 98.

${ }^{148} \mathrm{Id}$.

${ }^{149} \mathrm{Id}$.

${ }^{150} \mathrm{Id}$.
}

${ }^{151}$ It is important to note that decisions and developments with the coronavirus vaccine change daily, and therefore, this information will be accurate for only some time.

${ }^{152}$ McKeever, supra note 43.

${ }^{153}$ Kliff, supra note 75.

${ }^{154}$ Andrew Restuccia, Biden Says U.S. Struck Deals for 200 Million More Covid-19 Vaccine Doses, WALL STREeT J. https: / / www.wsj.com/articles/biden-says-u-s-struck-deals-for200-million-more-covid-19-vaccine-doses-

11613080885 ?mod=searchresults_pos3\&page $=1 \quad$ (last updated Feb. 12, 2021) 
would in order to combat the high demand for a vaccine. ${ }^{155}$ All showing the expedited effort to distribute the vaccine.

As companies begin to roll out the vaccine, each state will be responsible for distribution, although the CDC "recommends health-care personnel and long-term care residents receive the first doses," followed by people over the age of sixty five. ${ }^{156}$ However, states are still running into problems as they try to rank which health care professionals are first in line because of the shortage of available vaccines and the need to store the vaccine in an extremely cold environment. ${ }^{157}$

A poll taken in May of 2020 found that less than half of Americans would commit to taking the vaccine because of mistrust and belief that it was not necessary. ${ }^{158}$ However, by January of 2021, almost 70\% of Americans were willing to get vaccinated, showing a more receptive attitude toward the vaccine. ${ }^{159}$ Places such as China, Mexico, and the United Kingdom all show a higher percentage of the population embracing the vaccine, while residents of Russia and France show more resistance. ${ }^{160}$

Additionally, some companies, such as Quantas Airlines and Ticketmaster, have discussed the possibility of requiring proof of immunity in order to gain venue access. ${ }^{161}$ Dr. L.J. Tan, an immunologist for the Immunization Action Coalition, explained why proof of immunity may not be possible or useful because it is unclear how long immunization from the vaccine will last. ${ }^{162}$ Dr. Dorit Rubenstein Reiss, a law professor at University of California Hastings School of Law, states there is little control over private or foreign companies in what they may enact as far as restrictions for nonvaccinated people. ${ }^{163}$

Additionally, there are different laws based on jurisdiction that may compel patients to get treatment for communicable diseases, such as tuberculosis. ${ }^{164}$

\footnotetext{
${ }^{155}$ McKeever, supra note 43.

${ }^{156} \mathrm{Id}$.

${ }^{157}$ Sarah Elizabeth Richards, Who is really 'first in line' for the vaccine? It depends on your state., NAT. GEO. (Dec. 11, 2020), https:/ / www.nationalgeographic.com/science/2020/12/whois-really-first-in-line-coronavirus-vaccine-states-notguaranteed/.

${ }^{158}$ Zakiya Whatley \& Titilayo Shodiya, Why So Many Americans Are Skeptical of a Coronavirus Vaccine, ScI. AM. (Oct. 12, 2020), https:/ / www.scientificamerican.com/article/why-so-manyamericans-are-skeptical-of-a-coronavirus-vaccine/.

${ }^{159}$ Pitrelli, supra note 20.

${ }^{160} \mathrm{Id}$. (showing only about $40 \%$ of citizens would get the vaccine).

${ }^{161}$ Elizabeth Yuko, Could Venues and Airlines Require Covid-19 Vaccinations for Entry?, ROLLING STONE MAGAZINE (Dec. 22, 2020), https:/ / www.rollingstone.com/culture/culture-features/couldvenues-and-airlines-require-covid-19-vaccinations-for-entry$1107002 /$.

${ }^{162} \mathrm{Id}$.
}

Depending on a person's past behavior and the potential for contagion, they may be held in quarantine to prevent the spread of an infectious disease even if not required to get specific treatment. ${ }^{165}$

The Supreme Court, in Jacobson $v$. Commonwealth of Massachusetts, upheld a state law requiring that individuals get a vaccine. ${ }^{166}$ In 1905, Henning Jacobson sued the Commonwealth of Massachusetts for requiring that he, either get a smallpox vaccine, or pay a penalty of $\$ 5 .{ }^{167}$ The Court held the state's authority to enact such a law stemmed from the state's police power. ${ }^{168}$ Jacobson tried to argue that requiring a vaccination was unconstitutional and amounts to assault, but the court reminds him that "persons and property are subjected to all kinds of restraints and burdens in order to secure the general comfort, health, and prosperity of the state."169 The Court responded that as a "principle of self-defense" the state "has the right to protect itself against an epidemic of disease which threatens the safety of its members." ${ }^{170}$

The Court acknowledges the people who may distrust vaccines, but it gives deference to the state legislature in ignoring those views. ${ }^{171}$ Further, the Court states:

[W]e are unwilling to hold it to be an element in the liberty secured by the Constitution of the United States that one person, or a minority of persons, residing in any community and enjoying the benefits of its local government, should have the power thus to dominate the majority when supported in their action by the authority of the state. ${ }^{172}$

Although Jacobson provides some precedent for the current situation, it is important to note potentially distinguishable facts. First, the vaccinations, as per the language of the statute, were to be provided free of charge. ${ }^{173}$ Although this mirrors the current situation at the time of this writing,

${ }^{163} \mathrm{Id}$.

${ }^{164}$ Carl H. Coleman, The Right to Refuse Treatment for Infectious Disease, ETHICS AND DRUG Resistance: COLlective ResponsibILITY FOR GLOB. PUb. HeAlth, 171, 173 (Oct. 27, 2020).

${ }^{165} \mathrm{Id}$. at 174 .

${ }^{166} \mathrm{Id}$. at 175 .

167 Jacobson v. Commonwealth of Massachusetts, 197 U.S. 11, 12 (1905).

${ }^{168} I d$. at 24-25 ("According to settled principles, the police power of a state must be held to embrace, at least, such reasonable regulations established directly by legislative enactment as will protect the public health and the public safety.").

${ }^{169} I d$. at 25-26 (internal quotation marks omitted).

${ }^{170} \mathrm{Id}$. at 27

${ }^{171} \mathrm{Id}$. at 30 ("It is no part of the function of the court or a jury to determine which one of two modes was likely to be the most effective for the protection of the public against disease.").

${ }^{172} I d$. at 38 .

${ }^{173} I d$. at 12 . 
there is no guarantee that COVID-19 vaccinations will be free in the future. ${ }^{174}$

Next, Jacobson's argument centered on the idea that the vaccine may be dangerous, rather than on a fundamental right, such as freedom of religion. ${ }^{175}$ Therefore, it is unclear how the court would rule in such a case, but recent activity shows religion may not bar a state from mandating vaccination. ${ }^{176}$ As of 2019, the states of New York, California, Mississippi, and West Virginia announced freedom of religion was no longer a valid exemption for the measles vaccine. ${ }^{177}$ The idea seems to contradict the universally known bioethical right to refuse medical treatment. ${ }^{178}$ However, if a compulsory vaccination is refused, there is no forced action, only exclusion from certain activities, such as school. ${ }^{179}$ Although this is a small distinction, it helps distinguish individual rights violations from permissible police power.

Finally, the Court also notes that there is an exception to the statute for children who are "unfit subjects for vaccination." 180 This caveat is important to keep in mind because it may play a part in the statute's constitutionality.

Other countries, such as Canada, have their own laws that may require treatment of infectious diseases that will apply to anyone coming into the country. ${ }^{181}$ The Court in Jacobson points to several more countries that have laws for compulsory vaccination, showing potential universal acceptance. ${ }^{182}$ It is unclear what restrictions countries will place on individuals because of the novel situation, but there are many potential limitations to travel and business because the virus is highly contagious and people mistrust the vaccine.

\footnotetext{
${ }^{174}$ Ries, supra note 82.

${ }^{175}$ See Jacobson, supra note 167.

${ }^{176}$ Hilary Brueck \& Julia Naftulin, New York is eliminating religious exemptions for vaccines. Here's a full state-by-state guide to vaccine exemptions in the US, INSIDER (Jun. 14, 2019, 8:12 AM), https:/ / www.insider.com/vaccine-exemptions-by-state-map2019-2.

${ }^{177} \mathrm{Id}$.

${ }^{178}$ Coleman, supra note 164 at 175.

${ }^{179} \mathrm{Id}$.

${ }^{180}$ See Jacobson, supra note 167 at 12.

${ }^{181}$ Coleman, supra note 164 at 174.

${ }^{182}$ See Jacobson, supra note 167 at 31.

${ }^{183}$ Karen Shwartz, I'm a U.S. Citizen. Where in the World Can I Go?, N.Y. TIMES (Jan. 21, 2020), https:/ /www.nytimes.com/article/coronavirus-travelrestrictions.html

${ }^{184} I d$.

${ }^{185}$ As of January, 2021.

${ }^{186}$ Megan Brenan, COVID-19 and Remote Work: An Update, GALLUP (Oct. 13, 2020), https://news.gallup.com/poll/321800/covidremote-work-update.aspx
}

\section{APPLICATION}

\section{How Will the World Look Different?}

The world experienced multiple changes with the coronavirus. First, several countries have either partially or completely closed their borders to travelers during the pandemic. ${ }^{183}$ Other countries require travelers to get a coronavirus test within three days before travelling in order to decrease the spread of the virus. ${ }^{184}$ Although airlines do not currently require a test before travel and the restrictions come from individual countries, there is a chance that could change in the future. ${ }^{185}$

Next, many people were working from home, although there has been an increase in people cautiously returning to their workplaces. ${ }^{186}$ However, Gallup polls show that two-thirds of Americans working from home would prefer to stay there, and half claim they are afraid of contracting the virus at work. ${ }^{187}$

Even with all the information and changes, several Americans are still hesitant to take the vaccine. ${ }^{188}$ The question remains, how will international travel and work be impacted by the pressure on current laws?

\section{a. Venues, Travel, and the Vaccine}

With the start of vaccine rollout, some companies, such as IBM, have started developing "vaccine passport" apps, ${ }^{189}$ as well as contact tracing apps. ${ }^{190}$ The goal of the apps is to create a platform to show proof of vaccination before entering a country or a large venue. ${ }^{191}$ The app would easily verify, potentially through a $Q R$ code, whether a person is vaccinated. ${ }^{192}$ Some people speculate this

${ }^{187} \mathrm{Id}$.

${ }^{188}$ Whatley et al., supra note 158.

${ }^{189}$ Rishi Iyengar, If you want to travel next year, you may need a vaccine passport, CNN BUSINESS, Dec 28, 2020 https://www.cnn.com/2020/12/27/tech/coronavirus-vaccinepassport-apps/index.html.

${ }^{190}$ Kif Leswing, As workplaces slowly reopen, tech companies smell a new multibillion dollar opportunity: Helping businesses trace coronavirus,

CNBC,

https://www.cnbc.com/2020/05/10/coronavirus-tracing-forworkplaces-could-become-new-tech-opportunity.html (last updated May, 10, 2020 2:13 PM EDT); see Cat Ferguson, Do digital contact tracing apps work? Here's what you need to know, MIT TECH. REVIEW (Nov. 20, 2020), https:/ / www.technologyreview.com/2020/11/20/1012325/dodigital-contact-tracing-apps-work-heres-what-you-need-to-

know / (describing a contact tracing app as an app that connects via Bluetooth with surrounding phones to alert others that were close to coronavirus).

${ }^{191}$ Iyengar, supra note 189.

${ }^{192} I d$. 
industry could be a multi-billion dollar opportunity because of the wide-spread need. ${ }^{193}$

One leading developer, Common Trust Network, is a Geneva-based nonprofit partnered with companies such as JetBlue and United Airlines. ${ }^{194}$ They started an app called CommonPass. ${ }^{195}$ Developers like CommonPass and IBM are working with countries to coordinate efforts in order to have international standards for the app so it can be interoperable among all countries. ${ }^{196}$ The goal is to operate in a way similar to email services, in that it can be used throughout international servers. ${ }^{197}$

Peter Vlitas, an executive of a travel services company tried the app while travelling on a United Airlines flight. ${ }^{198}$ Once the app was downloaded, it informed him he needed to test negative for coronavirus, then "directed him to a rapid-testing center at the airport." ${ }^{199}$ Once he took the test, the results were uploaded to his phone with a confirmation code. ${ }^{200}$

However, there are still several hurdles the apps must overcome. First, the companies need to make sure people feel comfortable using an app that shares their personal medical information. ${ }^{201}$ Other concerns over whether this heightened surveillance borders on civil liberty interference. ${ }^{202}$ Developers address these concerns by stressing that privacy is one of their main concerns, and by creating options that allow the user to determine how much information they want to provide to the airlines or other businesses. ${ }^{203}$

Another concern arises because many people do not own smartphones. ${ }^{204}$ Companies would need a way to make sure people without smartphones and, therefore, without apps, can still prove their vaccination no matter where they are without concern of fraud. ${ }^{205}$

\footnotetext{
${ }^{193}$ Leswing, supra note 190.

${ }^{194}$ Iyengar, supra note 189.

${ }^{195} \mathrm{Id}$.

${ }^{196} I d$.

${ }^{197}$ Id.
}

${ }^{198}$ Natasha Singer, Vaccinated? Show Us Your App, N.Y. TIMES, https: / www.nytimes.com/2020/12/13/technology/coronavir us-vaccine-apps.html (last updated Feb 4, 2021).

${ }^{199} \mathrm{Id}$.

${ }^{200} I d$.

${ }^{201}$ Iyengar, supra note 189.

202 Singer, supra note 198.

${ }^{203}$ Iyengar, supra note 189.

${ }^{204}$ Id.; Lindsey Muscato \& Cat Ferguson, Will you have to carry a vaccine passport on your phone? , MIT TECH. REVIEW (Dec. 21, 2020), https:/ / www.technologyreview.com/2020/12/21/1015353/cov id-vaccine-passport-digital-immunity-record/ ("Some people can't or don't want to use smartphones for their medical records, meanwhile. This may be especially true for those hardest hit by the pandemic, including elderly, homeless, and undocumented people.").
Additional concerns arise with the use of the vaccine and whether it meets each country's standards. ${ }^{206}$ For example, one of the Chinese vaccines provides only an $85 \%$ efficacy rate, whereas the Moderna and Pfizer vaccines both have a 95\% efficacy rate. ${ }^{207}$ Again, there is no evidence that the vaccine prevents the spread of coronavirus or how long it lasts. ${ }^{208}$ It is unclear how countries will monitor the type of vaccine they require when entering their country.

Governments will have a harder time requiring vaccination than privately owned venues and businesses. ${ }^{209}$ "Mandatory vaccination could be challenged in court as a violation of religious liberty and antidiscrimination protections." ${ }^{210}$ However, as noted earlier in Jacobson, the government may be able to mandate compulsory vaccination in general. ${ }^{211}$ The WHO will need to modify vaccination rules now that coronavirus has become a global pandemic. ${ }^{212}$ However, this may prove to be difficult because the $\mathrm{WHO}$ has only ever required one vaccine for immunization (the yellow fever vaccine), and it would need acceptance from all 194 member countries. ${ }^{213}$

Ideally, these vaccine passes and apps would work because people would be eager to get the vaccine and return to normal. ${ }^{214}$ Additionally, Delta Air Lines CEO admitted that vaccinations will most likely become mandatory in order to travel internationally. ${ }^{215}$ In order to succeed, there needs to be mass agreement among countries and individuals regarding the vaccine and apps.

\section{b. Workers and the Vaccine}

As the vaccine rolls out, employers are wondering how to ensure safety with employees coming back to work and whether they can mandate vaccination. ${ }^{216}$ Although

${ }^{205}$ Iyengar, supra note 189.
${ }^{206} \mathrm{Id}$.
${ }^{207}$ Id.; Avera Writers, I Got the COVID-19 Vaccine - Now What?
AVERA (Jan. 12, https://www.avera.org/balance/infectious-disease/i-got-thecovid-vaccine/ (explaining it is unknown how long the vaccine will give immunity or if it protects the vaccinated person from passing on the virus to others).

${ }^{208}$ Iyengar, supra note 189.

${ }^{209}$ Stephanie Baker \& Tara Patel, The Coronavirus Vaccine Could Be the Ultimate Gateway Drug, BlOOMBERG BusinessweEK, Dec 15, 2020 https://www.bloomberg.com/news/articles/2020-1216/covid-vaccine-businesses-hope-immunity-passports-willboost-economies.

${ }^{210} I d$.

${ }^{211}$ See Jacobson, supra note 167.

${ }^{212}$ Baker et al., supra note 209.

${ }^{213} I d$.

${ }^{214} \mathrm{Id}$.

${ }^{215}$ Pitrelli, supra note 20.

216 Tessa Cranfield, Paul Cutrone, Julia Gorham, \& Daniel Waldman, Mandatory COVID-19 Vaccination - The International 
vaccination mandates are still in question, workplaces may easily mandate coronavirus contact tracing apps, allowing employees to feel safer. ${ }^{217}$

[I]nternational employers are considering their options to mandate or direct employees to get vaccinated as part of their overall organizational business continuity strategies and to manage the health and safety of employees, workers, and their underlying customers/client base for those with outward facing businesses. ${ }^{218}$

To many employer's dismay, people have been pushing back against getting the vaccine, especially in France and the Netherlands. ${ }^{219}$ Some professions, such as healthcare workers, may be reasonably and lawfully directed under local authority to get a vaccine. ${ }^{220}$ However, it still may not be universally enforceable because some countries leave vaccination decisions up to the individual. ${ }^{221}$ But, some countries so require vaccination or provide financial incentives to their own citizens for getting vaccinated. ${ }^{222}$ However, even countries with mandatory vaccination laws may choose to only loosely enforce compulsory vaccination or even may use the term "mandatory" differently than the United States. ${ }^{223}$

The potential repercussions from employees include "breach of contract, constructive dismissal, statutory claims for detriment/adverse action, discrimination, health and safety or workers compensation claims if an employee became ill from the vaccine." 224 The problem poses serious questions when the employee deals with several customers in a day, thus causing an occupational hazard. ${ }^{225}$

Although businesses may consider offering incentives to encourage employees to get the vaccine, there is also the

Employment Landscape, JDSUPRA (Dec 17, 2020), https:/ / www.jdsupra.com/legalnews/mandatory-covid-19vaccination-the-31125/.

${ }^{217}$ Leswing, supra note 190.

${ }^{218}$ Cranfield et al., supra note 216.

${ }^{219}$ Id.; Holly Ellyatt, France's vaccine-skepticism is making its Covid immunization drive much harder, CNBC, https:/ / www.cnbc.com/2021/01/13/france-swhy-france-is-themost-vaccine-skeptical-nation-on-earth.html (last updated Jan. 13, 2021, 1:12 AM EST) (finding the French people distrust the government because of previous health scandals false information spread on social media).

${ }^{220}$ Cranfield et al., supra note 216.

${ }^{221} \mathrm{Id}$.

${ }^{222}$ Erin Walkinshaw, Mandatory Vaccinations: The international landscape, CMAJ (Nov. 8, 2011), https://www.ncbi.nlm.nih.gov/pmc/articles/PMC3216445/.

${ }^{223}$ Id. (stating Latvia uses the term "mandatory" for state institutions and vaccine providers).

${ }^{224}$ Cranfield et al., supra note 216. possibility that workers may continue to work from home, even as the pandemic gets better. ${ }^{226}$ Some businesses may be considering a hybrid working situation, which may open the door for more international employees. ${ }^{227}$

Further, workers who often fly, either domestically or internationally, for their job will need to comply with airline requirements, which may include vaccination or proof of health. ${ }^{228}$ This rule might make their job either impossible or incredibly difficult if they do not opt for a vaccine. $^{229}$

Some states already require that patients can only refuse treatment if it is for religious reasons ${ }^{230}$ although exemptions vary considerably from state to state. ${ }^{231}$ However, "[i]t is unclear whether compelled treatment for infectious disease would be permitted under international human rights law." ${ }^{232}$ Proposed laws offer isolation for people who refuse to get treatment or vaccination, ${ }^{233}$ but that may not be feasible depending on occupation.

Currently, the best option for businesses is offering incentives to their employees. ${ }^{234}$ Although vaccines are currently operated by the government, businesses could offer to pay for vaccines when they become private or offer certain benefits, such as an extra vacation day. ${ }^{235}$

\section{What Are Our Options?}

In order to avoid what the South African government calls a "vaccine apartheid," international governments must take several steps to ensure compatibility with vaccinations and laws. ${ }^{236}$ Global health has taken several steps back during the pandemic as well as education, hunger, and violence. ${ }^{237}$

To begin, a group of government leaders from several countries need to meet and agree to a plan of action

${ }^{225} \mathrm{Id}$.

226 Nickie Rowley, Is Working From Home Here to Stay?, ENTREPRENEUR (Jan. 21, 2021), https://www.entrepreneur.com/article/362595.

${ }^{227} \mathrm{Id}$.

${ }^{228}$ Cranfield et al., supra note 216.

${ }^{229} \mathrm{Id}$.

${ }^{230}$ Coleman, supra note 164.

${ }^{231}$ Walkinshaw, supra note 222.

${ }^{232}$ Coleman, supra note 164.

${ }^{233} \mathrm{Id}$.

${ }^{234}$ Cranfield et al., supra note 216.

${ }^{235} \mathrm{Id}$.

${ }^{236}$ Lawrence O. Gostin, Eric A. Friedman, \& Suerie Moon, Wealthy Countries Should Share Vaccine Doses Before It Is Too Late, FOREIGN AFFAIRS (Jan. 19, 2021), https: / / www.foreignaffairs.com/articles/world/2021-0119/wealthy-countries-should-share-vaccine-doses-it-too-late. ${ }^{237} \mathrm{Id}$. 
regarding intellectual property. Although the United States, as well as others, report their opposition to patent pooling in organizations like CTAP, ${ }^{238}$ countries failed to provide any clear, persuasive plans to set international standards. An alternative to the CTAP disagreement would be for member States of the WTO to agree to suspend their agreement to opt out of Article 31bis of the TRIPS agreement. ${ }^{239}$ Regardless of whether governments choose to use CTAP, Article 31bis, or something else, agreement is essential to stop the disjointed application of intellectual property rights.

Towards the beginning of the pandemic, several global leaders met to discuss cooperation efforts to combat the pandemic, including a "cooperation pledge" from higher income countries not to keep research from others. ${ }^{240}$ The virtual meeting resulted in a call for $\$ 8$ billion in global donations for vaccine treatment and development, including governments as well as individual contributions from celebrities such as Madonna. ${ }^{241}$ Several countries, such as France, Germany, and Canada, all contributed over 500 million euros to the pledge, with the United States failing to contribute anything. ${ }^{242}$ However, this meeting took place before a vaccine was developed, and therefore leaders must plan a new meeting to set forth clear and cooperative efforts.

Furthermore, companies must agree to standard regulations that will be required before attending largenumber gatherings or workspaces. Complications arise because "countries are developing apps independently, and there are no global standards." ${ }^{243}$ However, although there are potential issues, as previously stated, this may be the most plausible way because apps may legally be the

\footnotetext{
${ }^{238}$ Reinsch et al., supra note 98.

239 See Love, supra note 116.

${ }^{240}$ Patrick Wintour, US stays away as world leaders agree action on Covid-19 vaccine, THE GUARDIAN (Apr. 24, 2020), https:/ /www.theguardian.com/world/2020/apr/24/us-staysaway-as-world-leaders-agree-action-on-covid-19-vaccine (noting, then president, Donald Trump did not appear at the meeting).

${ }^{241}$ Robin Emmott \& Francesco Guarascio, World leaders pledge \$8 billion to fight COVID-19 but U.S. steers clear, REUTERS (May 4, 2020, 1:11 AM), https://www.reuters.com/article/us-healthcoronavirus-eu-virus / world-leaders-pledge-8-billion-to-fight-
} covid-19-but-u-s-steers-clear-idUSKBN22G0RM.

${ }^{242}$ Bill Chappell, World Leaders Pledge \$8 Billion To Fight COVID19; U.S. Skips Meeting, NPR (May 5, 2020, 11:32 AM ET), https://www.npr.org/sections/coronavirus-live-

updates /2020/05/05/850604277/world-leaders-pledge-8billion-to-fight-covid-19-u-s-skips-meeting.

${ }^{243}$ Show evidence that apps for COVID-19 contact tracing are secure and effective, NATURE (Apr. 29, 2020), https: / www.nature.com/articles/d41586-020-01264-1.

${ }^{244}$ See Leswing, supra note 190.

${ }^{245}$ Associated Press, Health Experts Blame Rapid Expansion for Vaccine Shortages, U.S. NEWS (Jan. 21, 2021), best way for employers to ensure their employees are safe. ${ }^{244}$ There are several options for employers to choose from to incorporate a safer environment, but none have seemed to dominate the market.

Finally, compulsory vaccination is a legal question still on the minds of many. At the time of this paper, vaccines are in short supply around the United States. ${ }^{245}$ However, once the vaccine becomes more readily available, several states may want to make the vaccine compulsory. All states have some set of vaccine requirements for children before they go to school, with the exception of certain medical exemptions. ${ }^{246}$ However, currently eighteen states allow exemption for personal reasons, in addition to religion. ${ }^{247}$

In order for vaccine herd immunity to work, more people need to get the vaccine to prevent spreading the virus to people who are unable to be vaccinated for medical reasons. ${ }^{248}$ However, several people are still opposed to getting the vaccine for differing reasons. ${ }^{249}$ Therefore, each state will need to decide whether they will make vaccination mandatory once more doses become available.

\section{CONCLUSION}

Ultimately, the best course of action will be worldwide agreement on matters from domestic businesses to international corporations and governments. Without agreements, the disruption of coronavirus will continue to divide and harm more people. Governments and businesses need to partner to find global solutions to problems such as vaccination, contact tracing, and travel guidelines.

The disjointed international efforts have shown countries lacked a strong international system for pandemics. ${ }^{250}$ It is

https: / www.usnews.com/news/health-news/articles/202101-21/us-vaccine-shortages-force-cancellations-andpostponements; Luke Money, Rong-Gong Lin Il, Colleen Shalby, \& Jaclyn Cosgrove, California is facing acute shortages of COVID-19 vaccine as concerns about equity rise, L.A. TIMES (Feb. 9, 2021), https://www.latimes.com/california/story/2021-02-09/seconddose-bottleneck-persists-in-l-a-county-despite-increases-incovid-19-vaccine-shipments.

246 Erik Skinner, State Vaccination Policies: Requirements and Exemptions for Entering School, NAT'L CONFERENCE OF STATE LEGISLATURES, Vol. 25, No. 48 (Dec. 2017), https://www.ncsl.org/research/health/state-vaccinationpolicies-requirements-and-exemptions-for-entering-school.aspx. ${ }^{247} \mathrm{Id}$.

248 Vaccines Protect Your Community, VACCINES.GOV, https://www.vaccines.gov/basics/work/protection (last reviewed Feb. 2020).

${ }^{249}$ Cranfield et al., supra note 216.

${ }^{250}$ Betsy McKay \& Phred Dvorak, A Deadly Coronavirus Was Inevitable. Why Was No One Ready?, THE WALl StREet J. (Aug. 13, 2020, 9:29 AM ET), https://www.wsj.com/articles/a-deadlycoronavirus-was-inevitable-why-was-no-one-ready-for-covid11597325213. 
essential to fill in the holes left by an incomplete international plan. Because coronavirus was not the first, and will not be the last, global pandemic. ${ }^{251}$ Additionally, several doctors predict COVID-19 is here to stay. ${ }^{252}$ Even with the vaccine, there are predictions of annual surges ${ }^{253}$ as well as mutations, leaving the potential for yearly booster shots, similar to a yearly flu shot. ${ }^{254}$

Several legal professionals think the United States trend throughout the pandemic will lead to lasting strict borders in the country. ${ }^{255}$ However, it is vital for the continued health of international trade relations and business that the United States, as well as other countries, come together to find a common path that addresses critical and common needs.

Because of the coronavirus, several laws, as well as common practices, are facing pressure to adapt to the changing world. However, these changes require global acceptance, as well as change, which is coming at a time of deep division in the United States. ${ }^{256}$ Airlines will need to communicate with countries in order to streamline safe travel. Competing technology companies will need to create an interoperable platform for all apps tracing coronavirus contact. Apps for vaccination and proof of health must be streamlined so that safety for those unable to get the vaccine remains top priority. ${ }^{257}$

None of the solutions are clear and many factors remain up in the air. International and domestic leaders as well as businesses must take the necessary time to consider a global plan to ensure international laws and communications remain effective in future pandemics.

$$
--0--
$$

${ }^{251}$ See id.

${ }^{252}$ Megan Scudellari, How the pandemic might play out in 2021 and beyond, NATURE (Aug. 5, 2020), https:/ / www.nature.com/articles/d41586-020-02278-5.

${ }^{253} \mathrm{Id}$.

${ }^{254}$ Corky Siemaszko, Get ready for Covid-19 vaccine booster shots at your next physical, experts warn, NBC NEWS (Feb. 10, 2021, 12:14 PM PST).
${ }^{255}$ Claire Parins \& Claire Stamler-Goody, How COVID-19 Could Change the Law, UNIV. OF CHI. LAW SCH. (Oct. 16, 2020), https:/ / www.law.uchicago.edu/news/how-covid-19-couldchange-law.

${ }^{256}$ Americans reflect on a divided nation: "This doesn't feel like America," CBS NEWS (Jan. 20, 2021, 8:41 AM), https://www.cbsnews.com/news/history-divided-unitedstates/.

${ }^{257}$ Iyengar, supra note 189. 
Journal Achieve Link:

https://abc.us.org/ojs/index.php/ajtp/issue/archive 